\title{
Haploidentical stem cell transplantation in adults for the treatment of hematologic diseases: results of a single center (CIC725)
}

\author{
Anastasia V. Beynarovich, Elena V. Babenko, Ivan S. Moiseev, Olesya V. Paina, Olga V. Pirogova, Tatiana A. Rudakova, \\ Tatyana L. Gindina, Elena I. Darskaya, Elena V. Morozova, Sergey N. Bondarenko, Ludmila S. Zubarovskaya, \\ Boris V. Afanasyev
}

R. Gorbacheva Memorial Research Institute of Children Oncology, Hematology and Transplantology at the First St. Petersburg State I. Pavlov Medical University

\author{
Dr. Anastasia V. Beynarovich, R. Gorbacheva Memorial \\ Research Institute of Children Oncology, Hematology and \\ Transplantology at the First St. Petersburg State I. Pavlov \\ Medical University, L. Tolstoy St 6-8, 197022, St. Petersburg, \\ Russia
}

\author{
Phone: +7 (911) 7728024 \\ E-mail: beynarovichn@gmail.com
}

Citation: Beynarovich AV, Babenko EV, Moiseev IS et al. Haploidentical stem cell transplantation in adults for the treatment of hematologic diseases: results of a single center (CIC725). Cell Ther Transplant 2019; 8(1): 26-35.

\section{Summary}

Allogeneic HSCT (allo-HSCT) is potentially curative option for a wide variety of malignant and nonmalignant disorders of hematopoiesis. For patients who lack an HLA-matched sibling, HLA-haploidentical related donors (haplo-HSCT) can be considered as alternative sources of donor grafts. The benefits of haplo-HSCT include immediate donor availability for patients who are in urgent need of the transplant. Besides, an availability of a related donor makes post-transplant donor-derived cellular therapy more easily accessible. In addition, the greater HLA mismatch associated with haploidentical HSCT (haplo-HSCT) may potentiate graft-versus-tumor (GVT) effects. The aim of our study was to summarize our single-center experience of haplo-HSCT performed with non-manipulated grafts in adult patients with different malignant diseases. The study included a total of 119 patients with different hematological disorders subjected to haplo-HSCT. At the time of analysis, median follow-up was 371 days (1-2219). Most frequent diagnosis in transplanted patients was acute leukemia. 67 (56\%) patients received haplo-HSCT as salvage therapy.

Overall survival with an observation term of 2 years was $40.3 \%$ for the general group. In particular, the two-year OS in patients transplanted in remissions of ALL and
AML was $57 \%$ and $46 \%$ respectively as compared to $22 \%$ and $15 \%$ for the patients transplanted in adverse disease status). Two-year event-free survival (EFS) and GVHD-free/relapse-free survival (GRFS) group proved to be $35.7 \%$ and $21 \%$ respectively. The cumulative incidence of acute GVHD grade II-IV and severe aGVHD grade III-IV was $19 \%$ and $10 \%$ respectively. The cumulative incidence of chronic GVHD (cGVHD) was 16\%. The cumulative incidence of relapse was $21 \%$. The overall transplant-associated mortality was $43 \%$ in the studied group. In conclusion, our results show that unmanipulated haplo-HSCT is reasonable treatment option for adult patients with different malignant disorders of hematopoiesis. However, such problems as higher rate graft failure, increased nonrelapse mortality (NRM) and post-transplant relapses remain extremely relevant.

\section{Keywords}

Allogeneic hematopoietic stem cell transplantation, haploidentical, adult patients, overall survival, post-transplant relapse, graft-versus-host disease, graft failure, post-transplant cyclophosphamide. 


\section{Introduction}

Allogeneic HSCT (allo-HSCT) is potentially curative option for a wide variety of malignant and nonmalignant disorders of hematopoiesis [1-4]. Historically, the best outcomes of allo-HSCT were obtained in cases when a donor was an HLA-matched sibling [5]. The probability of having an HLA-matched sibling donor is approximately thirty percent [6]. For patients who lack an HLA-matched sibling, alternative sources of donor grafts can be found in suitable HLA-matched adult unrelated donors (MUD), unrelated umbilical cord blood (UCB) donors, and partially HLA-mismatched-unrelated donors (mMUD) or HLA-haploidentical related donors (haplo-HSCT) [1, 8]. Despite the increasing number of volunteers in unrelated donor registries, the likelihood of finding a suitable matched unrelated donor is modest $[6,7]$. However, haploidentical donor can be found for nearly every patient. The use of haploidentical donors is not limited by racial/ethnic HLA diversity or unusual HLA phenotypes due to mixed racial ancestry [6]. The benefits of haplo-HSCT include immediate donor availability for patients who need the transplant as soon as possible. Besides, post-transplant donor-derived cellular therapy is more easily accessible with the use of a related donor. In addition, the greater HLA mismatch associated with haploidentical HSCT (haplo-HSCT) may potentiate graft-versus-tumor (GVT) effects. However, this method was historically associated with poor engraftment, high risk of early death, and severe graftversus-host disease (GVHD).

Earlier attempts at using unmanipulated haploidentical transplant were associated with an unacceptably high rate of GVHD related mortality. Several strategies have been evolved over the past decade to avoid these disadvantages. The advent of T-cell depleted haplo-SCT has allowed better control of the severe GVHD risk [9]. However, this approach was associated with a high rate of graft failure due to host T-lymphocytes that survived the conditioning regimen [1012]. Later studies have shown that murine and human hematopoietic stem cells have veto cell activity and infusion of a large number of donor hematopoietic stem cells can overcome the MHC barrier and promote engraftment [13-15]. Megadose human CD34+ stem cells (on average $>10 \times 10^{6}$ CD34+ cells/kg body weight) with minimal T cell contamination (a median of $1 \times 10^{4} / \mathrm{kg}$ weight) have been successfully used in haploidentical transplantation, which results in high-level engraftment of MHC disparate stem cells. The use of intensive conditioning without additional GVHD prophylaxis led to the result that nearly $80 \%$ of patients achieved primary engraftment and only $18 \%$ of the patients developed grade II-IV acute GVHD [16, 17]. The major disadvantages of T-cell depleted grafts are both high rate of relapse and nonrelapse mortality (NRM) due to slow immune reconstitution and, thus, infectious complications [18].

Another method to manipulate the T-cell depleted graft is co-infusion of donor-derived regulatory T-cells (Tregs). $\mathrm{CD} 4+\mathrm{CD} 25+$ regulatory T-cells have been shown to suppress proliferative responses of CD4+CD25- T-cells to alloantigenic stimulation in vitro and are required for ex vivo tolerization of donor T-cells, which results in their reduced potential to induce aGVHD $[19,20]$. Despite promising results, this approach is costly and technically demanding, which limits its application to experienced centers.

Another innovative approach is to selectively deplete T-cells responsible for GVHD (TCR alpha-beta) while sparing gamma-delta T-cells ( $\gamma \delta$ T-cells). Gamma-delta T-cells account for $1 \%$ to $10 \%$ of peripheral T-cells and have MHC-unrestricted innate cytotoxic activity against tumor cells [2123 ]. The use of TCR $\alpha \beta / C D 19$-depleted stem cells essentially accelerated immune recovery.

A more recent strategy is to selectively deplete naive T-cells to separate GVHD and the GVL effect. Naive T-cells with CD45RA expression demonstrate to be the most allo-reactive among the T-cell subsets. Ex vivo depletion of CD45RA T-cells and adoptive transfer of CD45RA-memory T-cells accelerate the immune reconstitution, increase the GVL effect while abrogating GVHD [24].

A group of Chinese researchers used a method based on G-CSF-stimulation of the donor, intensified immunosuppression, antithymocyte globulin as in vivo T-cell depletion, and combination of peripheral blood stem cell and bone marrow allografts. Despite satisfactory relapse-free survival rates, acceptable NRM and engraftment, relatively high incidence of severe acute and chronic GVHD was observed. In addition, the standard-risk patients often suffered with opportunistic infections $[25,26]$.

Trying to improve these results, Italian research team modified this approach through using only BM allografts and adding basiliximab which allowed them to achieve a lower rate of chronic GVHD that included both forms, limited and extensive [27].

Another approach to allo-HSCT was developed in Baltimore (USA) based on non-manipulated graft followed by post-transplant cyclophosphamide injection (PtCy) [28, 29]. This approach has overcome most obstacles historically connected with haplo-HSCT. Thus, recent changes in haploHSCT methodology have allowed to improve its results.

The aim of this study was to compare the efficiency of various haplo-HSCT approaches used in our HSCT center.

\section{Patients and methods}

The study included 119 patients transplanted from a haploidentical donor (haplo-HSCT) between 2006 and 2018 at the R. M. Gorbacheva Institute of Children Oncology (CIC 725). Their clinical parameters are shown in Table 1. Nine patients received second haplo-HSCT, due to graft failure in 8 cases and relapse in one patient. Eight patients were transplanted from the same donor and one patient from the other donor. Median age was 26 years (18-63), 61 patients were males (51\%). Most frequent diagnosis in transplanted patients was acute leukemia $(77 \%, \mathrm{n}=92)$. Primary diagnoses were ALL (31\%, $n=37)$, AML (45\%, n=53), ABL (2\%, n=2), myeloproliferative neoplasms $(8 \%, n=9)$, lymphoproliferative disorders $(13 \%, n=16)$, severe aplastic anemia $(1 \%, n=2)$. Median follow-up was 371 days (1-2219). A total of 46 patients with acute leukemia (38\%) had complete remission at the time of HSCT (the first complete remission $-80 \%, n=37$, the $2 \mathrm{~d}$ or 
greater remission $-20 \%, n=9), 33 \%$ patients $(n=30)$ had relapse, $15 \%$ patients $(n=14)$ had refractory disease. Thus, 67 (56\%) patients in the general group received haplo-HSCT as salvage therapy. Non-myeloablative, or reduced-intensity conditioning (RIC) was employed in $81 \%(n=96)$ and the myeloablative treatment (MAC) was used in 19\% $(n=23)$. Seventy-seven patients (65\%) received busulfan, 14 patients (12\%), melphalan, and 28 patients (23\%) were administered other alkylating agents. Bone marrow was the graft source for $61 \%$ patients $(n=73)$, peripheral blood (PBSC) - 39\% patients $(n=46)$. Mean transplant CD34+cell and CD3+cell dose was $5 \times 10^{6} / \mathrm{kg}(1.5-10)$ and $10 \times 10^{7} / \mathrm{kg}(2-44)$ respectively for bone marrow as a graft source, whereas it was $5.1 \times 10^{6} / \mathrm{kg}$ (1-16.6) and $10 \times 10^{7} / \mathrm{kg}$ (3-47) respectively for recipients who received $\mathrm{PBSC}$ as a source of graft.
GVHD prophylaxis based on post-transplant cyclophosphamide (PTCY-based GVHD prophylaxis) $50 \mathrm{mg} / \mathrm{kg}$ at day +3 , +4 was employed in 78 patients $(66 \%)$, also these recipients received tacrolimus $0.03 \mathrm{mg} / \mathrm{kg} / \mathrm{day}$ and MMF $30-45 \mathrm{mg} / \mathrm{kg}$ starting from day +5 . Eleven patients $(9 \%)$ received a T-cell manipulated transplant. The protocol of depletion and HSCT included conditioning according to the GIAC protocol, depleted PBSC in combination with native BM and ATGAM, tacrolimus, MMF.

A total of 30 patients (25\%) received GVHD prophylaxis with ATGAM- $31(26 \%)$ and alemtuzumab in 5 patients (4\%). Tacrolimus was used for GVHD prophylaxis in 93 patients (72\%), cyclosporin A - in 18 patients (14\%). Clinical characteristics of the study group are presented in Table 1.

Table 1. Clinical characteristics of the study group

\begin{tabular}{|l|l|}
\hline Parameter & Haplo-HSCT \\
\hline Total number & 119 \\
\hline Gender, \% m/f & $61 \% / 39 \%$ \\
\hline Age, years, median (range) & $26(18-63)$ \\
\hline Diagnosis & \\
Acute myeloblastic leukemia (AML) & $53(45 \%)$ \\
Acute lymphoblastic leukemia (ALL) & $37(31 \%)$ \\
Other diseases & \\
Acute biphenotypic leukemia (ABL) & $2(1.5 \%)$ \\
Myeloproliferative neoplasia (MPN) & $9(8 \%)$ \\
Malignant lymphoma & $16(13 \%)$ \\
AA (aplastic anemia) & $2(1.5 \%)$ \\
\hline Salvage group & $67(56 \%)$ \\
\hline Disease risk index & \\
1 & $11(9 \%)$ \\
2 & $36(30 \%)$ \\
3 & $58(49 \%)$ \\
\hline 4 & $14(12 \%)$ \\
\hline Graft source & \\
Bone marrow (BM) & $73(61 \%)$ \\
\hline Peripheral blood stem cells (PBSC) & $46(39 \%)$ \\
\hline Conditioning: & \\
Myeloablative (MAC) & $23(19 \%)$ \\
Reduced-intensity (RIC) & $96(81 \%)$ \\
\hline GVHD prophylaxis: & \\
Posttransplant cyclophosphamide (PTCy) -based & $78(66 \%)$ \\
Manipulated transplant & $11(9 \%)$ \\
ATGAM & $31(26 \%)$ \\
\hline CD34+ cells, 106/kg of recipient mass & $5(1.5-10)$ \\
Bone marrow (BM) & $5.1(1-16.6)$ \\
\hline Peripheral blood stem cells (PBSC) & \\
\hline
\end{tabular}


Clinical diagnosis of acute (aGVHD) and chronic GVHD (cGVHD) was based on standard criteria and confirmed by histological analysis of skin and/or rectal biopsy specimens. First-line and second-line therapy for GVHD was provided according to institutional protocols.

For statistical evaluation, SPSS Statistics v.17 was used. Twoyear time frame was selected for all outcomes. In the group description overall survival (OS), event-free survival (EFS) and GVHD-free/relapse-free survival (GRFS) were calculated using Kaplan-Meier methodology.

A

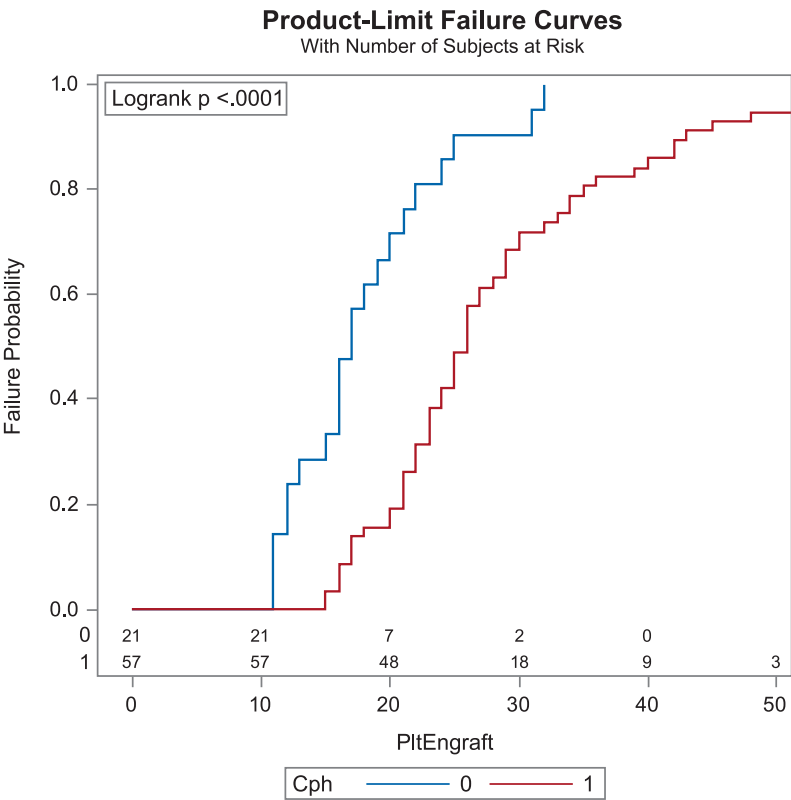

B

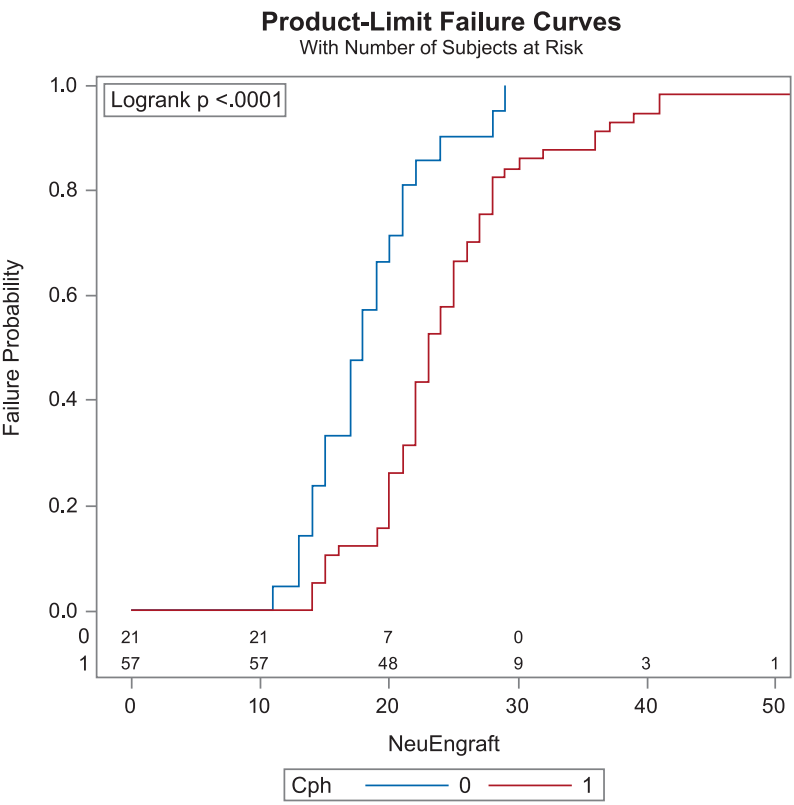

Figure 1. Engraftment terms for the patients with different GvHD prophylaxis. Abscissa, observation terms, days; ordinate, graft failure probability. Red graphs, recovery in cyclophosphamide-based GvHD prophylaxis; blue graphs, $\mathrm{Cy}$-free regimens

Box A, platelet engraftment time; Box B, neutrophil engraftment time.
The comparisons were made using the log-rank test. The difference levels of $\mathrm{p}<0.05$ were considered significant. $\mathrm{Cu}$ mulative incidence analysis was used for aGVHD, cGVHD, relapse incidence and NRM. The comparisons were made using Gray test. The parameters with p.value $<0.1$ were selected for further Fyne-Gray regression analysis.

\section{Results}

\section{Hematopoietic recovery}

Stem cell engraftment after haplo-HSCT was documented in $61 \%$ of total group of patients $(n=72)$. CD34+cell level less than $3 \times 10^{6} / \mathrm{kg}$ significantly reduced the engraftment rate $(\mathrm{p}=0.02)$. Median neutrophil engraftment time (absolute neutrophil count reached $\geq 0.5 \times 10^{9} / \mathrm{L}$ for 3 consecutive days) was day +22 (11-58) and median platelet engraftment time (platelet count reached $\geq 20 \times 10^{9} / \mathrm{L}$ for 7 consecutive days without transfusion) was day +23 (11-60). In group PTCY-based GVHD prophylaxis the engraftment time was delayed (Fig. 1). 21 recipient (18\%) had primary graft failure, including resistant relapse in 6 patients.

\section{Survival data}

Two-year overall survival (OS) in general group proved to be $40.3 \%$ after haplo-HSCT (Fig. 2). Particularly, the twoyear OS in patients transplanted in remission of ALL and AML was $57 \%$ and $46 \%$ respectively as compared to $22 \%$ and $19 \%$ for the patients transplanted in adverse disease status $(p=0.07)$. Overall survival for patients with lymphoproliferative disorders, acute leukemia and other diseases proved to be $82 \%, 31 \%$, and $54 \%$ respectively ( $p=0.002$, Fig. 2 ). For patients who received haplo-HSCT as salvage therapy two-year OS was $29 \%$ as compared to $57 \%$ for patients transplanted in remissions of diseases $(\mathrm{p}=0.001)$. Two-year event-free survival (EFS) and GVHD-free/relapse-free survival (GRFS) group proved to be $35.7 \%$ and $21 \%$ respectively (Fig. 3). Event-free survival for patients with lymphoproliferative disorders was significant higher compared with other groups: $76 \%$ vs $26 \%$ for patient with acute leukemia and $54 \%$ for patients with the other diseases ( $p=0.01$, Fig. 2 ). With the current sample size GVHD prophylaxis based on post-transplant cyclophosphamide had no significant impact for twoyear OS and EFS ( $p=0.15$ for OS and $p=0.28$ for EFS, Fig. 2)

In the multivariate analysis, we found that advanced disease phase ( $\mathrm{p}=0.03,95 \%$ CI HR 1.074-4.286), acute GVHD $(\mathrm{p}=0.0039,95 \%$ CI HR $0.145-0.69)$, and the earlier terms after transplantation $(\mathrm{p}=0.0042,95 \% \mathrm{CI}$ HR $0.711-0.938)$ were negative predictors of survival (Fig. 4).

\section{Posttransplant complications}

Out of the 72 patients with engraftment, the cumulative incidence of acute GVHD grade II-IV and severe aGVHD grade III-IV was $19 \%$ and $10 \%$ respectively. Use of manipulated transplants and PBSC as a source of graft significantly increased the incidence of aGVHD. However, in regression analysis these parameters had no significant impact. The cumulative incidence of chronic GVHD (cGVHD) was $16 \%$. The only factor that significantly increased the risk of cGVHD was the preceeding aGVHD $(\mathrm{p}=0.03)$. 
A

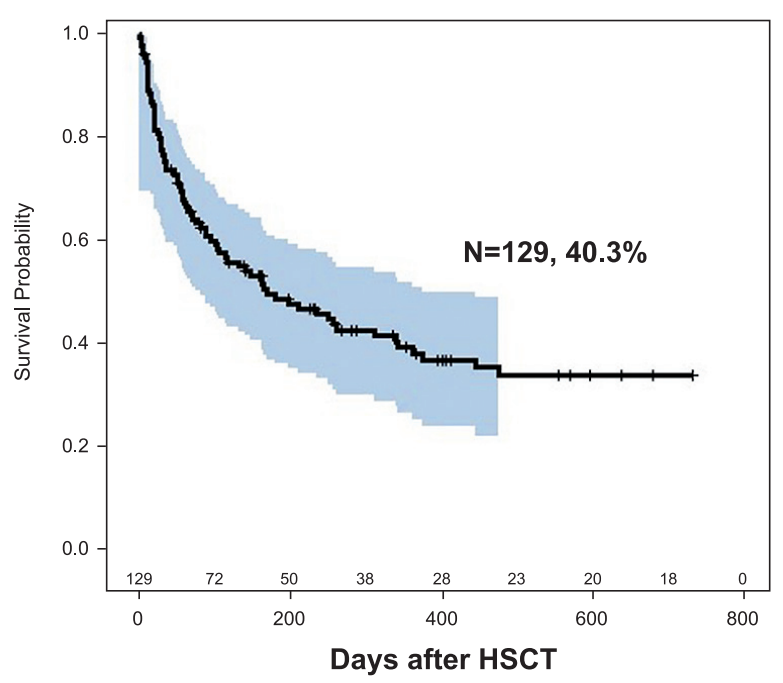

C

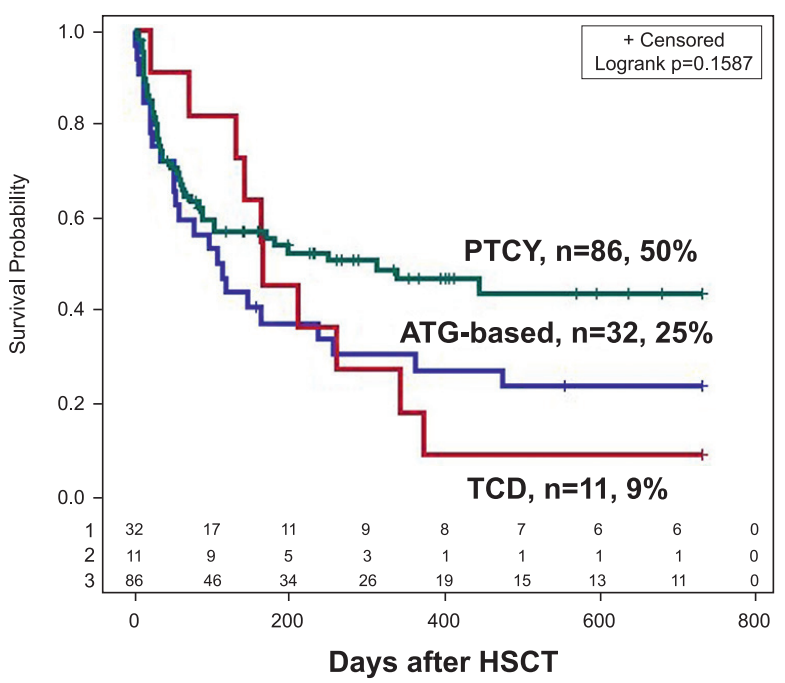

$\mathrm{E}$

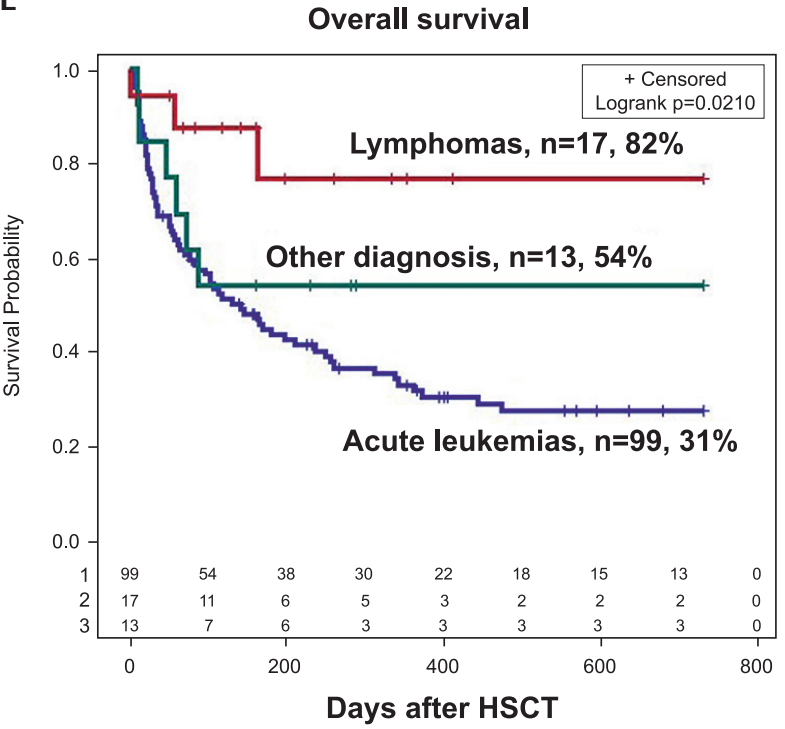

B

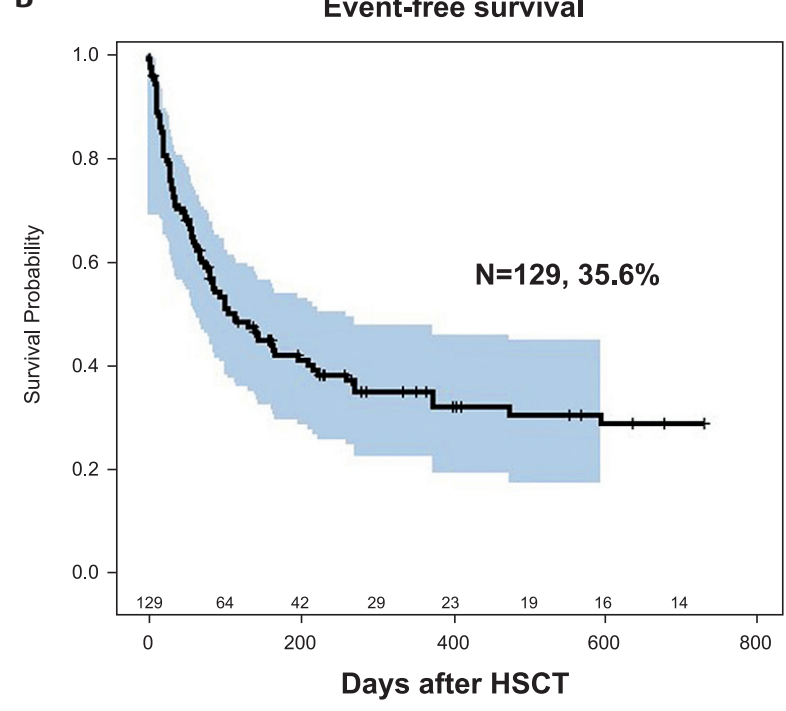

D

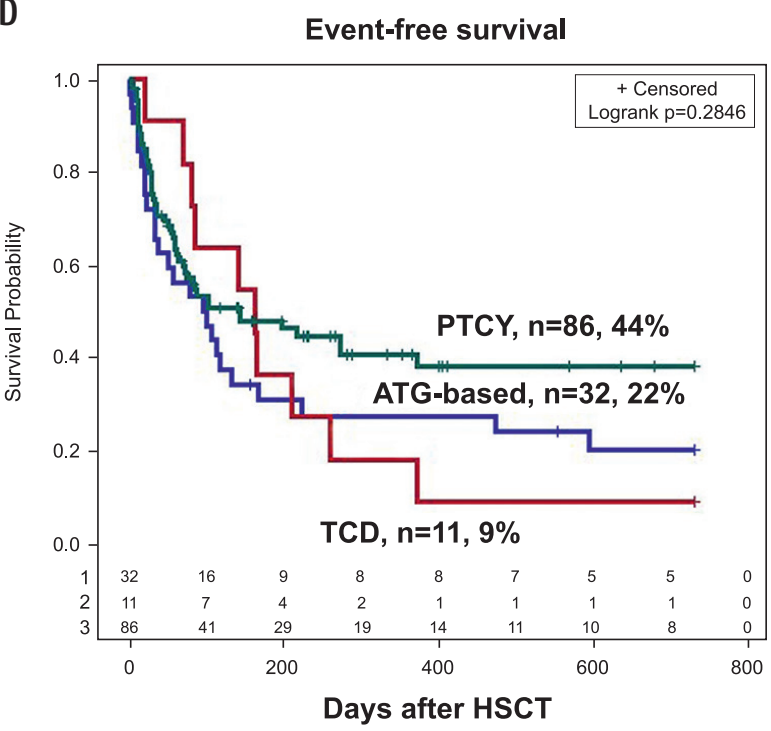

$\mathbf{F}$

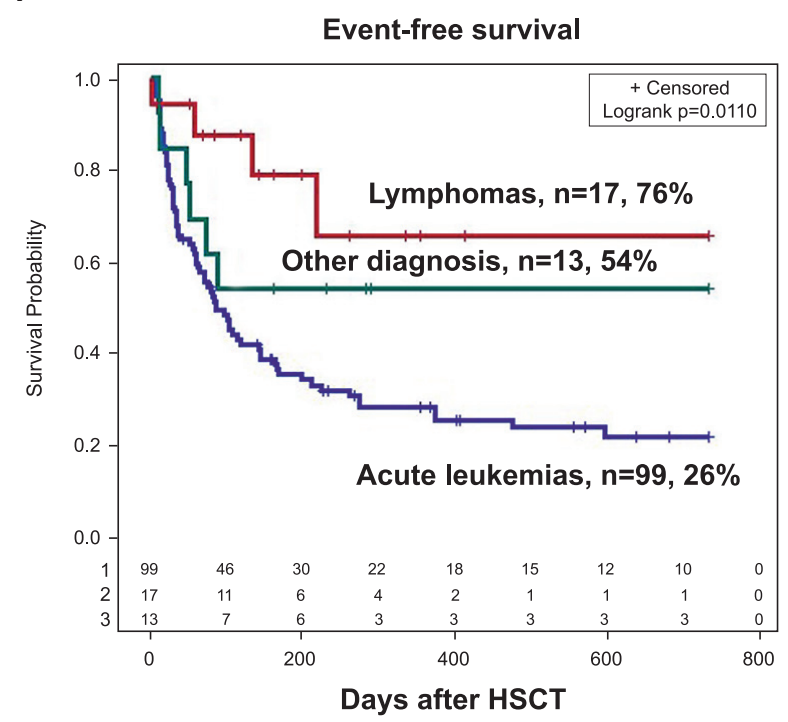

Figure 2. Clinical outcomes of haplo-HSCT. Abscissa, observation terms, days; ordinate, survival probability

Note: A, B, two-year overall survival and event-free survival in general group; C, D, two-year overall survival and event-free survival depending on the GVHD prophylaxis (PTCY, post-transplant cyclophosphamide; TCD, T-cell depleted, ATG-based GVHD prophylaxis with ATGAM); E, F, two-year overall survival and event-free survival among patients with different disorders. 


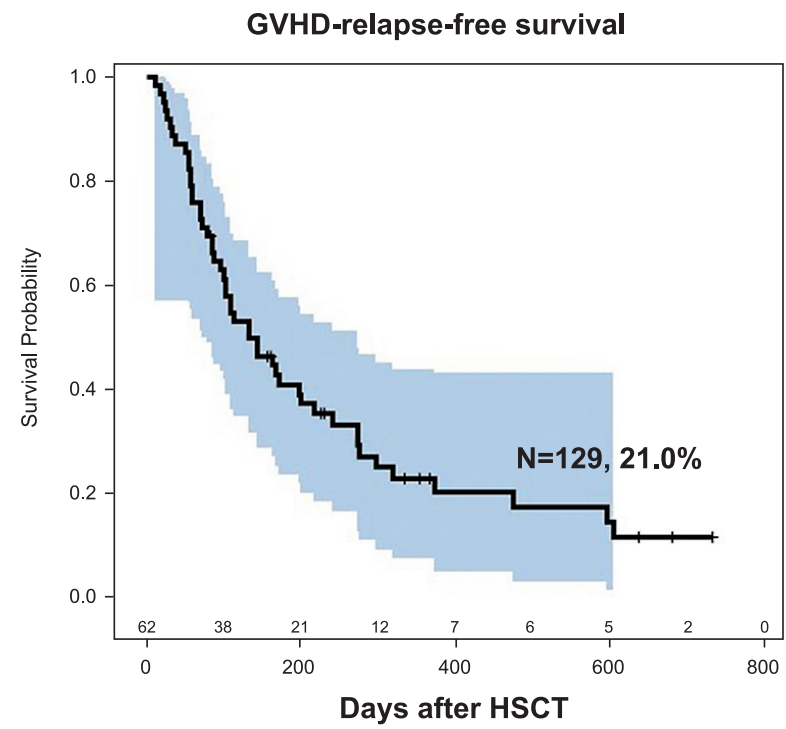

Figure 3. GVHD-free/relapse-free survival in general group. Abscissa, observation terms, days; ordinate, survival probability

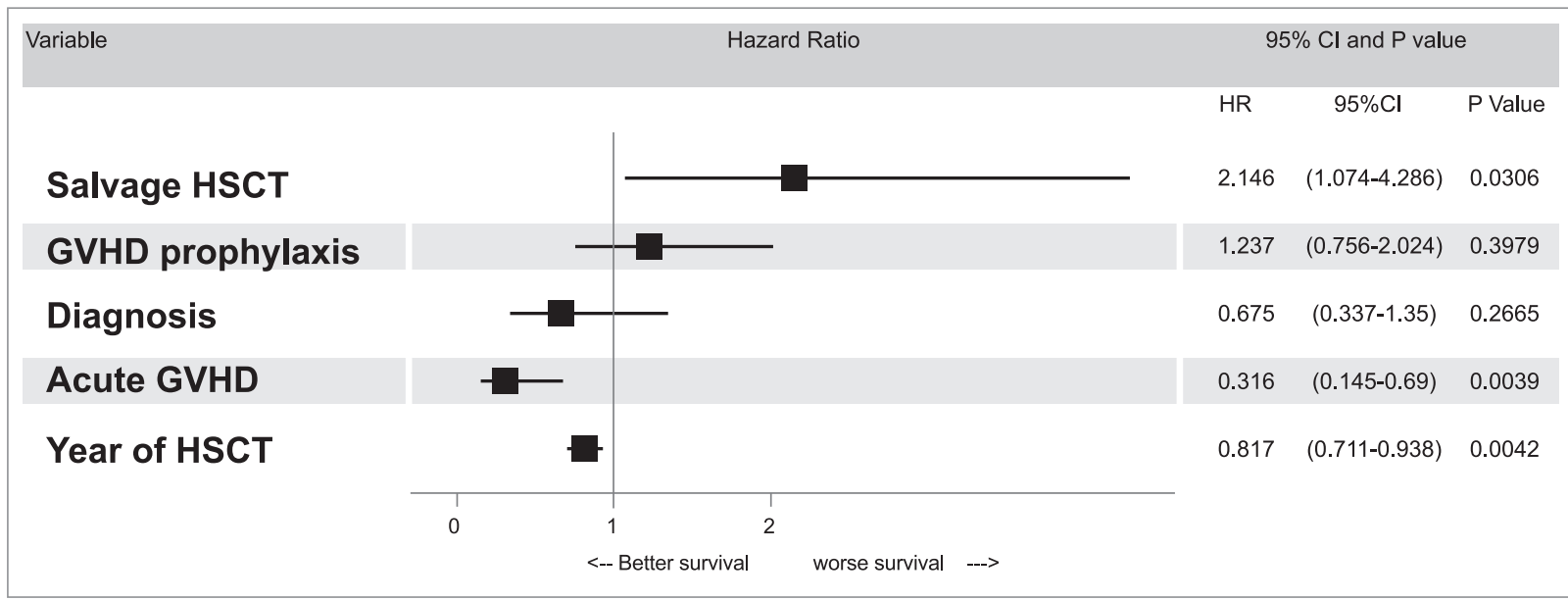

Figure 4. Subgroup analysis of event- free survival post-HSCT and relative risk factors (a Forest plot)

The cumulative incidence of relapse was $21 \%$. In multivariate analysis, we found that BM as a source of graft ( $p=0.003$, 95\%CI HR 0.10-0.64), high/very high DRI group ( $\mathrm{p}=0.04$, 95\%CI HR 1.02-2.72) were associated with a significantly increased incidence of relapse.

The overall transplant-associated mortality was $43 \%$ in the studied group. For patients who received haplo-HSCT as salvage therapy ( $47 \%$ vs $36 \%, \mathrm{p}=0.03)$ and also in the group of patients with acute leukemia (48\% vs 38\% for patients with the other diseases, $\mathrm{p}=0,04$ ) overall transplant-associated mortality was significantly higher. In multivariate analysis only advanced disease status did significantly impact the transplant-associated mortality ( $\mathrm{p}=0.03,95 \%$ CI HR 1.03-3.1).

Eighty-four recipients (65\%) developed clinically significant complications. The main complications were as follows: grade II-III mucositis (53 recipients, 63\%); hemorrhagic cystitis (20 recipients, $24 \%$ ); sepsis (41 recipients, $49 \%$ ); severe sepsis with septic shock (30 recipients, $36 \%$ ); invasive fungal disease (17 recipients, 20\%); clinically significant CMV reactivation (27 recipients, $32 \%$ ).
The main cause of death up to day $+100(n=48)$ were infectious complications $(n=32,67 \%)$. Clinical and molecular relapses up to 100 days were observed in 7 recipients (15\%).

Causes of death at later post-transplant period $(n=28)$ were presented by infectious complications $(n=13,46 \%)$ and progression of primary disease $(n=15,54 \%)$.

\section{Discussion}

Allo-HSCT of the non-manipulated primed bone marrow from a haploidentical donor proved to be an effective approach to achieve clinical remission in children and adolescents with malignant disorders of hematopoiesis [30]. However, the role of this type of transplantation in the treatment of adult patients is still not completely determined. Immediate availability of a haploidentical donor makes this approach an attractive treatment option for patients who lack an HLA-identical donor or those for whom a MUD cannot be found in a timely manner. In recent years, use of post-transplant cyclophosphamide for GVHD prophylaxis after T-cell repleted haploidentical HSCT has yielded 
encouraging results in adults. In terms of survival, the outcomes following haploidentical HSCT with post-transplant cyclophosphamide have been comparable to MRD or MUD transplant in several non-randomized studies. Particularly, in cases where an HLA-identical sibling donor is not available for an AML patient with adverse disease a haploidentical donor may be used with the expectation of similar results, compared with those achieved with 10/10 matched and 9/10 mismatched UD unrelated donors . In our study, in a group of patients with acute leukemia, both in remission and in relapse, we obtained results comparable to the results of multicenter studies.

PTCy-based haplo-HSCT is associated with similar results with respect to NRM, OS, and EFS with those of conventional transplantations for patients with Hodgkin lymphoma. In a recent study by Martínez $\mathrm{C}$ et al, overall survival, relapse incidences and non-relapse mortality were 67\%, 39\% and $17 \%$ [31]. In the group of patients transplanted in our BMT center, these results were as follows: OS was 79\%, relapse incidences - 15\% and non-relapse mortality was $14 \%$. In addition, several studies demonstrated the advantages for haplo-HSCT compared with the conventional transplantations for patients with $\mathrm{r} / \mathrm{r}$ Hodgkin lymphoma allowing long-term remissions with limited toxicity, low GVHD incidence and early immune reconstitution to be achieved [32]. The data obtained allow of considering haplo-HSCT to be an acceptable option for patients with refractory/resistant (R/R) Hodgkin lymphoma.

The main causes of death according to our results were infectious complications in the pre-engraftment period and due to slow immune reconstitution after HSCT. The majority of patients were patients with relapsed/refractory acute leukemia who previously received significant number of chemotherapy courses. It is known, that the risk for colonization resistant bacteria is highest among patients with acute leukemia or high-risk MDS. Importantly, the treatment of these diseases prior to allo-HSCT typically requires one or more hospital admissions for high-dose chemotherapy and broad-spectrum antibiotics for fever and neutropenia, which presumably increases the risk of colonization multidrug resistant bacteria. Bacterial colonization in the setting of allo-HSCT confers an extraordinarily high risk for bloodstream infection in the early post-transplant period, with a considerable decrement in survival [33]. An additional adverse factor for patients with refractory disease was iron overload due to multiple blood transfusions. In accordance with our previous findings, we observed that the baseline increase of serum ferritin contents is associated with higher risk of febrile episodes, infectious conditions, and slower recovery of myeloid cells [34].

Post-transplant relapses represent the major problem for these patients. High percentage of relapses in our group of patients (39\%) may be explained by the disease status at the time of haplo-HSCT. The majority of the patients (56\%, $\mathrm{n}=67$ ) received haplo-HSCT as a salvage therapy. According to the data published by Italian group, the relapse rates may reach $50 \%$ in this subset of patients $[35,36]$. A strong graft-versus-leukemia effect mediated by alloreactive NK cells, resulting in reduced risk for relapse, was documented in adult patients with acute myeloid leukemia, undergoing T-cell-depleted HLA-haploidentical HSCT. Among receptors influencing NK cell function, the killer-cell immunoglobulin-like receptors (KIRs) are of particular importance. Two basic KIR haplotypes can be found in humans: the group A and the group B haplotypes [37]. Noteworthy, in a recent study by Michaelis et al, 57 adults with hematological malignancies given T-cell-depleted haploidentical HSCT were found to have a reduced risk for relapse when transplanted from a KIR haplotype B donor [38]. The presence of activating KIR, as seen in KIR haplotype B might reduce relapse in myeloid malignancies [39]. In our study, KIR genotyping was not carried out.

Graft failure remains a serious obstacle to the success of haplo-HSCT. Our haplo-HSCT data show unsatisfactory primary graft failure rate (18\%). Most commonly, graft failure mediated by residual cellular immunity (recipient T-cells or NK-mediated allograft rejection) or humoral immunity (HLA-specific antibodies). In our study, we did not screen HLA -antibodies. Patients sensitized by blood transfusions, but also by pregnancy are at increased risk of rejection. The question of effective depletion of NK- cells still remains unresolved. Another major status for graft failure which may explain the observed results is the advanced disease status [40]. This might have significantly contributed to our results. The approach to dealing with the graft failure is the implementation of novel bridge therapies.

\section{Conclusion}

In summary, our results show that unmanipulated haploHSCT is a reasonable treatment option for adult patients with different malignant disorders of hematopoiesis. The major advantage of haploidentical HSCT is the almost universal availability of highly motivated donors who can be mobilized in a short time at a relatively low cost. However, the problematic issue is the higher rate of graft failure, increased non-relapse mortality (NRM) and post-transplant relapses. To improve the results of haplo-HSCT, the appropriate multicenter studies are required.

\section{Conflict of interest}

The authors report no conflicts of interest.

\section{References}

1. Bashey A, Solomon SR. T-cell replete haploidentical donor transplantation using post-transplant CY: an emerging standard-of-care option for patients who lack an HLA-identical sibling donor. Bone Marrow Transplant. 2014; 49(8): 999-1008.

2. Santoro N, Ruggeri A, Labopin M, Bacigalupo A, Ciceri F, Gülbaş Z, Huang H, Afanasyev B, Arcese W, Wu D, Koc Y, Tischer J, Santarone S, Giebel S, Mohty M, Nagler A. Unmanipulated haploidentical stem cell transplantation in adults with acute lymphoblastic leukemia: a study on behalf of the Acute Leukemia Working Party of the EBMT. J Hematol Oncol. 2017;10(1):113. doi: 10.1186/s13045-017-0480-5. 
3. Brissot E, Labopin M, Ehninger G, Stelljes M, Brecht A, Ganser A, Tischer J, Kröger N, Afanasyev B, Finke J, Elmaagacli A, Einsele H, Mohty M, Nagler A. Haploidentical versus unrelated allogeneic stem cell transplantation for relapsed/ refractory acute myeloid leukemia: a report on 1578 patients from the Acute Leukemia Working Party of the EBMT. Haematologica. 2019;104(3):524-532.

4. Thomas' Hematopoietic Cell Transplantation. 3rd ed. Blackwell Publishing, Malden, MA; 2004.

5. Szydlo R, Goldman JM, Klein JP, Gale RP, Ash RC, Bach FH, Bradley BA, Casper JT, Flomenberg N, Gajewski JL, Gluckman E, Henslee-Downey PJ, Hows JM, Jacobsen N, Kolb HJ et al. Results of allogeneic bone marrow transplants for leukemia using donors other than HLA-identical siblings. J Clin Oncol. 1997;15(5):1767-1777.

6. Gragert L, Eapen M, Williams E, Freeman J, Spellman S, Baitty R, Hartzman R, Rizzo JD, Horowitz M, Confer D, Maiers M. HLA match likelihoods for hematopoietic stem-cell grafts in the U.S. registry. N Engl J Med. 2014; 371(4):339348.

7. Fabricius WA, Ramanathan M. Review on haploidentical hematopoietic cell transplantation in patients with hematologic malignancies. Adv Hematol. 2016; 2016:5726132. doi: $10.1155 / 2016 / 5726132$.

8. Bejanyan N, Haddad H, Brunstein C. Alternative donor transplantation for acute myeloid leukemia. J Clin Med. 2015; 4(6):1240-1268.

9. Reisner Y, Kapoor N, Kirkpatrick D, Pollack MS, Cunningham-Rundles S, Dupont B, Hodes MZ, Good RA, O'Reilly RJ. Transplantation for severe combined immunodeficiency with HLA-A,B,D,DR incompatible parental marrow cells fractionated by soybean agglutinin and sheep red blood cells. Blood. 1983;61(2):341-348.

10. Kernan NA, Flomenberg N, Dupont B, R. J. O'Reilly. Graft rejection in recipients of T-cell-depleted HLA-nonidentical marrow transplants for leukemia. Identification of host-derived antidonor allocytotoxic T lymphocytes. Transplantation. 1987;43(6):842-7.

11. Martin PJ. The role of donor lymphoid cells in allogeneic marrow engraftment. Bone Marrow Transplant. 1990; 6:283-289.

12. Reisner Y, Ben-Bassat I, Douer D, Kaploon A, Schwartz E, Ramot B. Demonstration of clonable alloreactive host $\mathrm{T}$ cells in a primate model for bone marrow transplantation. Proc Natl Acad Sci USA. 1986;83:4012-4015.

13. Bachar-Lustig E, Rachamim N, Li HW, Lan F, Reisner Y. Megadose of T cell-depleted bone marrow overcomes MHC barriers in sublethally irradiated mice. Nat Med. 1995; 1 (12): 1268-73.

14. Gur H, Krauthgamer R, Berrebi A, Klein T, Nagler A, Tabilio A, Martelli MF, Reisner Y .Tolerance induction by megadose hematopoietic progenitor cells: expansion of veto cells by short-term culture of purified human CD34(+) cells. Blood. 2002;99(11):4174-81.
15. Reisner Y, Gur H, Reich-Zeliger S, Martelli MF, Bachar-Lustig E. Hematopoietic stem cell transplantation across major genetic barriers: tolerance induction by megadose CD34 cells and other veto cells. Ann NY Acad Sci. 2005;1044:70-83. Review.

16. Aversa F, Tabilio A, Terenzi A, Velardi A, Falecetti F, Giannoni C, Iacucci R, Zei T, Martelli MP, Gambelunghe C. Successful engraftment of T-cell-depleted haploidentical "three-loci" incompatible transplants in leukemia patients by addition of recombinant human granulocyte colony-stimulating factor-mobilized peripheral blood progenitor cells to bone marrow inoculum. Blood. 1994;84(11):3948-3955.

17. Aversa F, Velardi A, Tabilio A, Reisner Y, Hammers MF. Haploidentical stem cell transplantation in leukemia. Blood Rev. 2001;15(3):111-119.

18. Ciceri F, Labopin M, Aversa F, Rowe JM, Bunjes D, Lewalle P, Nagler A, Di Bartolomeo P, Lacerda JF, Lupo Stanghellini MT, Polge E, Frassoni F, Martelli MF, Rocha V. A survey of fully haploidentical hematopoietic stem cell transplantation in adults with high-risk acute leukemia: a risk factor analysis of outcomes for patients in remission at transplantation. Blood. 2008;112:3574-3581.

19. Hoffmann P, Ermann J, Edinger M, Fathman CG, Strober S. Donor-type CD4(+)CD25(+) regulatory T cells suppress lethal acute graft-versus-host disease after allogeneic bone marrow transplantation. J Exp Med. 2002;196(3):389-399.

20. Nguyen VH, Shashidhar S, Chang DS, Ho L, Kambham N, Bachmann M, Brown JM, Negrin RS. The impact of regulatory $\mathrm{T}$ cells on T-cell immunity following hematopoietic cell transplantation. Blood. 2008;111(2):945-953.

21. Minculescu L, Sengeløv H. The role of gamma delta T cells in haematopoietic stem cell transplantation. Scand J Immunol. 2015;81:459-468.

22. Lang P, Feuchtinger T, Teltschik HM, Schwinger W, Schlegel P, Pfeiffer M, Schumm M, Lang AM, Lang B, Schwarze CP, Ebinger M, Urban C, Handgretinger R. Improved immune recovery after transplantation of TCR $\alpha \beta /$ CD19-depleted allografts from haploidentical donors in pediatric patients. Bone Marrow Transplant. 2015;50 Suppl 2:S6-10.

23. Maschan MA. Alpha/beta- T lymphocyte depletion: a reliable platform for development of hematopoietic stem cell transplants from haploidentical donors. Russian J Pediatric Hematol Oncol. 2015; 2(3): 34-38 (In Russian).

24. Teschner D, Distler E, Wehler D, Frey M, Marandiuc D, Langeveld K, Theobald M, Thomas S, Herr W. Depletion of naive $\mathrm{T}$ cells using clinical grade magnetic CD45RA beads: a new approach for GVHD prophylaxis. Bone Marrow Transplant. 2014;49(1):138-144.

25. D.-P. Lu, L. Dong, T. Wu, Huang XJ, Zhang MJ, Han W, Chen H, Liu DH, Gao ZY, Chen YH, Xu LP, Zhang YC, Ren HY, Li D, Liu KY.Conditioning including antithymocyte globulin followed by unmanipulated HLA-mismatched/haploidentical blood and marrow transplantation can achieve comparable outcomes with HLA-identical sibling transplantation. Blood. 2006; 107(8): 3065-3073. 
26. X. J. Huang, D. H. Liu, K. Y. Liu, Xu LP, Chen H, Han W, Chen YH, Wang JZ, Gao ZY, Zhang YC, Jiang Q, Shi HX, Lu DP.. Haploidentical hematopoietic stem cell transplantation without in vitro T-cell depletion for the treatment of hematological malignancies. Bone Marrow Transplant. 2006; 38:291-297.

27. P. Di Bartolomeo, S. Santarone, G. De Angelis. Haploidentical, unmanipulated, G-CSF-primed bone marrow transplantation for patients with high-risk hematologic malignancies. Blood. 2013; 121(5):849-857.

28. Luznik L, O'Donnell PV, Symons HJ, Chen AR, Leffell MS, Zahurak M, Gooley TA, Piantadosi S, Kaup M, Ambinder RF, Huff CA, Matsui W, Bolaños-Meade J, Borrello I, Powell JD, et al. HLA-haploidentical bone marrow transplantation for hematologic malignancies using nonmyeloablative conditioning and high-dose, post transplantation cyclophosphamide. Biol Blood Marrow Transplant. 2008; 14(6):641-650.

29. Moiseev IS, Pirogova OV, Alyanski AL, Babenko EV, Gindina TL, Darskaya EI, Slesarchuk OA, Bondarenko SN, Afanasyev BV. Graft-versus-host disease prophylaxis in unrelated peripheral blood stem cell transplantation with post-transplantation cyclophosphamide, tacrolimus and mycophenalate mofetil. Biol Blood Marrow Transplant. 2016; 22(6):1037-1042.

30. Paina OV, Kozhokar PV, Borovkova AS, Frolova AS, Ekushov KA, Bykova TA, Rakhmanova ZZ, Galas MA, Khabirova AG, Markova IV, Semenova EV, Bondarenko SN, Babenko EV, Gindina TL, Alyanskiy AL et al. Ten-year experience of allogeneic haploidentical hematopoietic stem cell transplantation with non-manipulated grafts in children and adolescents with high-risk acute leukemia. Cell Ther Transplant. 2018: 7(2): 20-27.

31. Martinez C, Gayoso J, Channels C, Finel H, Peggs K, Dominietto A, Castagna L, Afanasyev B, Robinson S, Blaise $\mathrm{D}$, Corradini $\mathrm{P}$, Itälä-Remes $\mathrm{M}$, Bermúdez $\mathrm{A}$, Forcade $\mathrm{E}$, Russo D, Potter M, McQuaker G, Yakoub-Agha I, Scheid C, Bloor A, Montoto S, Dreger P, Sureda A. Post-transplantation cyclophosphamide-based haploidentical transplantation as alternative to matched sibling or unrelated donor transplantation for Hodgkin lymphoma: A registry study of the Lymphoma Working Party of the European Society for Blood and Marrow Transplantation. J Clin Oncol. 2017;35(30):3425-3432.

32. Burroughs LM, O'Donnell PV, Sandmaier BM, Storer BE, Luznik L, Symons HJ, Jones RJ, Ambinder RF, Maris MB, Blume KG, Niederwieser DW, Bruno B, Maziarz RT, Pulsipher MA, Petersen FB, Storb R, Fuchs EJ, Maloney DG. Comparison of outcomes of HLA-matched related, unrelated, or HLA-haploidentical related hematopoietic cell transplantation following nonmyeloablative conditioning for relapsed or refractory Hodgkin lymphoma. Biol Blood Marrow Transplant. 2008;14(11):1279-1287.

33. Marasco V, Forcina A, Lorentino F, Greco R. Pre-transplant colonization by a multidrug-resistant Gram negative bacteria has no impact on overall survival and mortality after hematopoietic stem cell transplantation: A single-center experience in 362 patients. J. Blood 2016 128:5743.
34. Mostafa Shaheen, Maria O. Ivanova, Ivan S. Moiseev, Sergey V. Bondarchuk, Boris V.Afanasyev. Impact of initial serum ferritin on early post-HSCT complications: a singlecenter study. Cell Ther Transplant. 2016;5(2): 40-49.

35. Solomon SR, Sizemore CA, SanacoreM, Zhang X, Brown S, Holland HK, Morris LE, Bashey A. Haploidentical transplantation using $\mathrm{T}$ cell replete peripheral blood stem cells and myeloablative conditioning in patients with high-risk hematological malignancies who lack conventional donors is well tolerated and produces excellent relapse-free survival: results of a prospective phase II trial. Biol Blood Marrow Transplant. 2012;18:1859-1866.

36. Aversa F, Terenzi A, Tabilio A et al. Full haplotype mismatched hematopoietic stem-cell transplantation: a phase II study in patients with acute leukemia at high risk of relapse. J Clin Oncol. 2005; 23(15):3447-3454.

37. Oevermann L, Michaelis SU, Mezger M et al. KIR B haplotype donors confer a reduced risk for relapse after haploidentical transplantation in children with ALL. Blood. 2014;124(17):2744-2747.

38. Michaelis SU, Mezger M, Bornhäuser M, Trenschel R, Stuhler G, Federmann B, Oevermann L, Kanz L, Handgretinger R, Bethge WA. KIR haplotype B donors but not KIR-ligand mismatch result in a reduced incidence of relapse after haploidentical transplantation using reduced intensity conditioning and CD3/CD19-depleted grafts. Ann Hematol. 2014;93(9):1579-1586.

39. Heidenreich S, Kröger N. Reduction of relapse after unrelated donor stem cell transplantation by KIR-based graft selection. Front Immunol. 2017; 8:41. Published 2017 Feb 8. doi:10.3389/fimmu.2017.00041.

40. Mattsson J, Ringdén O, Storb R. Graft failure after allogeneic hematopoietic cell transplantation. Biol Blood Marrow Transplant. 2008;14(1 Suppl 1):165-170. 


\title{
Гаплоидентичная трансплантация костного мозга для лечения взрослых пациентов с различными заболеваниями: опыт одного центра (CIC725)
}

\author{
Анастасия В. Бейнарович, Елена В. Бабенко, Иван С. Моисеев, Олеся В. Паина, Ольга В. Пирогова, \\ Татьяна А. Рудакова, Татьяна Л. Гиндина, Елена И. Дарская, Елена В. Морозова, Сергей Н. Бондаренко, \\ Людмила С. Зубаровская, Борис В. Афанасьев \\ НИИ детской онкологии, гематологии и трансплантологии им. Р. М. Горбачевой Первого Санкт-Петербургского \\ государственного медицинского университета, Санкт-Петербург, Россия
}

\section{Резюме}

Аллогенная трансплантация костного мозга (аллоТГСК) является потенциальной возможностью излечения злокачественных и незлокачественных заболеваний кроветворения. Для пациентов, у которых отсутствует HLA-совместимый сиблинг, можно использовать HLA-гаплоидентичного донора (гапло-ТГСК) в качестве альтернативного источника трансплантата. Преимуществом гапло-ТГСК является немедленная доступность донора для пациентов, которым необходимо выполнение трансплантации в короткие сроки. Кроме того, наличие родственного донора делает более доступной клеточную терапию после трансплантации. Также, большее несоответствие по генам HLA-системы в случае гаплоидентичной трансплантации, может потенциировать эффект «трансплантат против опухоли». В этом отчете представлен анализ результатов гапло-ТГСК, выполненных в нашем центре взрослым пациентам с различными злокачественными заболеваниями, при использовании неманипулированного трансплантата. На момент анализа медиана наблюдения составила 371 день (1-2219). Основным диагонозом был острый лейкоз. Шестидесяти семи пациентам (56\%) гапло-ТГСК была выполнена в качестве терапии спасения. Общая выживаемость в течении 2 лет в исследуемой группе составила $40,3 \%$. В частности, двухлетняя общая выживаемость у пациентов с ОЛЛ и ОМЛ в ремиссии заболевания, составила $57 \%$ и $46 \%$ соответственно в сравнении с $22 \%$ и $15 \%$ у пациентов с продвинутыми стадиями заболеваний. Безрецидивная выживаемость в течение 2 лет, а также выживаемость без проявлений оРТПХ и рецидива заболевания в общей группе составили $35,7 \%$ и $21 \%$ соответственно. Частота возникновения острой PTПX II-IV степени и тяжелой РTПX III-IV степени составили 19\% и $10 \%$ соответственно. Частота хронической РТПХ составила 16\%. Частота возникновения рецидива заболевания составила 21\%. Трансплантационная летальность исследуемой группе 43\%. В заключение необходимо отметить, что наши результаты показывают, что гапло-ТГСК с использованием неманипулированного трансплантата является приемлемым методом лечения взрослых пациентов с различными злокачественными заболеваниями кроветворения. Однако такие проблемы, как высокая частота неприживления, высокая трансплантационная летальность, а также посттрасплантационные рецидивы остаются чрезвычайно актуальными.

\section{Ключевые слова}

Аллогенная трансплантация гемопоэтических стволовых клеток, гаплоидентичная, взрослые пациенты, общая выживаемость, рецидив после трансплантации, реакция «трансплантат против хозяина», неприживление трансплантатата, посттрансплантационный циклофосфамид. 